University of Montana

ScholarWorks at University of Montana

10-1998

\title{
Increased Photosynthesis Offsets Costs of Allocation to Sapwood in An Arid Environment
}

\author{
Eileen V. Carey \\ Ragan M. Callaway \\ University of Montana - Missoula, Ray.Callaway@mso.umt.edu \\ Evan H. DeLucia
}

Follow this and additional works at: https://scholarworks.umt.edu/biosci_pubs

Part of the Biology Commons

Let us know how access to this document benefits you.

\section{Recommended Citation}

Carey, Eileen V.; Callaway, Ragan M.; and DeLucia, Evan H., "Increased Photosynthesis Offsets Costs of Allocation to Sapwood in An Arid Environment" (1998). Biological Sciences Faculty Publications. 310. https://scholarworks.umt.edu/biosci_pubs/310

This Article is brought to you for free and open access by the Biological Sciences at ScholarWorks at University of Montana. It has been accepted for inclusion in Biological Sciences Faculty Publications by an authorized administrator of ScholarWorks at University of Montana. For more information, please contact scholarworks@mso.umt.edu. 


\title{
INCREASED PHOTOSYNTHESIS OFFSETS COSTS OF ALLOCATION TO SAPWOOD IN AN ARID ENVIRONMENT
}

\author{
Eileen V. Carey, ${ }^{1,3}$ Ragan M. Callaway, ${ }^{2}$ and Evan H. Delucia ${ }^{1}$ \\ 'Department of Plant Biology, University of Illinois, Urbana, Illinois 61801 USA \\ ${ }^{2}$ Division of Biological Sciences, University of Montana, Missoula, Montana 59812 USA
}

\begin{abstract}
We assessed the effect that varying patterns of biomass allocation had on growth of ponderosa pine (Pinus ponderosa) growing in the desert climate of the Great Basin and the montane climate of the eastern Sierra Nevada. Prior work established that desert trees have lower leaf: sapwood area ratios than montane trees $\left(0.104\right.$ and $0.201 \mathrm{~m}^{2} /$ $\mathrm{cm}^{2}$, respectively) and proportionally greater stem respiration. Sapwood: leaf mass ratios are also greater and increase more as a function stem diameter in desert than in montane trees. We hypothesized that this increased allocation of carbon to stem sapwood and stem respiration in large trees could decrease growth rates in the desert compared to the montane environment, in addition to any growth reduction imposed by drought on physiology and growth processes. Trees of all diameters (dbh) in the desert environment had lower relative growth rates (RGRs) than montane trees (e.g., for a $30 \mathrm{~cm}$ dbh tree, RGR $=0.012 \mathrm{vs}$. $0.021 \mathrm{~kg} \cdot \mathrm{kg}^{-1} \cdot \mathrm{yr}^{-1}$, respectively). However, growth rates of desert and montane trees declined similarly with increasing dbh and did not reflect diverging sapwood : leaf mass ratios.

Alternatively, we hypothesized that desert trees may increase rates of photosynthetic carbon accumulation (per unit leaf area) with diameter, thereby compensating for increased sapwood respiration. Leaf nitrogen $(\mathrm{N})$ concentration and stable-carbon isotope composition $\left(\delta^{13} \mathrm{C}\right)$ were measured to examine size-dependent and seasonally integrated photosynthetic capacity within desert and montane environments. Nitrogen concentration was correlated with photosynthetic capacity. Leaf nitrogen $(\mathrm{N})$ concentration and $\delta^{13} \mathrm{C}$ values were greater in the desert (e.g., in 1-yr-old needles, desert $=1.11 \%$ and $-22.96 \%$; montane $=0.94 \%$ and $-24.20 \% o$ ) and differed between desert and montane trees as a function of dbh. In desert trees, leaf nitrogen concentration in 1-yr-old through 5-yr-old needles increased with $\mathrm{dbh}$, and carbon isotope composition in 1-yr-old needles increased with dbh, suggesting increased photosynthetic capacity and photosynthetic rates with increasing tree size. Needle nitrogen concentration and $\delta^{13} \mathrm{C}$ values decreased or remained constant with dbh in montane trees. Desert trees had greater light extinction coefficients and retained fewer needle cohorts. Our results suggest that increased allocation to heterotrophic stem tissue at the expense of photosynthetic tissue does not always incur a reduction in tree growth as predicted by current models of forest productivity.
\end{abstract}

Key words: canopy light interception; carbon isotope ratio; forest productivity; forest stand development; leaf age; leaf area index; light extinction coefficient; nitrogen; photosynthetic capacity; Pinus ponderosa; relative growth rate.

\section{INTRODUCTION}

The balance between biomass allocated to photosynthetic vs. heterotrophic tissue largely determines forest growth and productivity and can be affected by climate (Waring and Schlesinger 1985, Gower et al. 1995). For example, in warm, dry environments trees allocate proportionally more biomass to sapwood and less to foliage than in cooler, moister environments, both among species (Waring and Schlesinger 1985) and within a species (Callaway et al. 1994, Mencuccini and Grace 1995). Proportional changes in leaf: sapwood area ratios within a species may provide a constant

Manuscript received 21 April 1997; revised 3 November 1997; accepted 12 November 1997; final version received 5 December 1997.

${ }^{3}$ Present address: Division of Biological Sciences, University of Montana, Missoula, Montana 59812 USA. water potential within tree stems in environments with different evaporative demands (Mencuccini and Grace 1995). However, the increase in sapwood biomass at the expense of photosynthetic biomass may decrease growth by increasing the carbon investment in constructing and maintaining proportionally more heterotrophic tissue (Poorter et al. 1990), particularly in warm climates.

Callaway et al. (1994) found that ponderosa pine (Pinus ponderosa Laws.) growing in a warm, dry desert allocated proportionally more biomass to sapwood and less to leaf area than trees in a cooler, moister montane environment $\left(0.104\right.$ and $0.201 \mathrm{~m}^{2}$ leaf area/ $/ \mathrm{cm}^{2}$ sapwood area, respectively). Differences in biomass allocation became more pronounced with increasing stem diameter, and for large desert trees $(>35 \mathrm{~cm} \mathrm{dbh})$ the ratio of leaf mass to sapwood mass was $30-50 \%$ less 


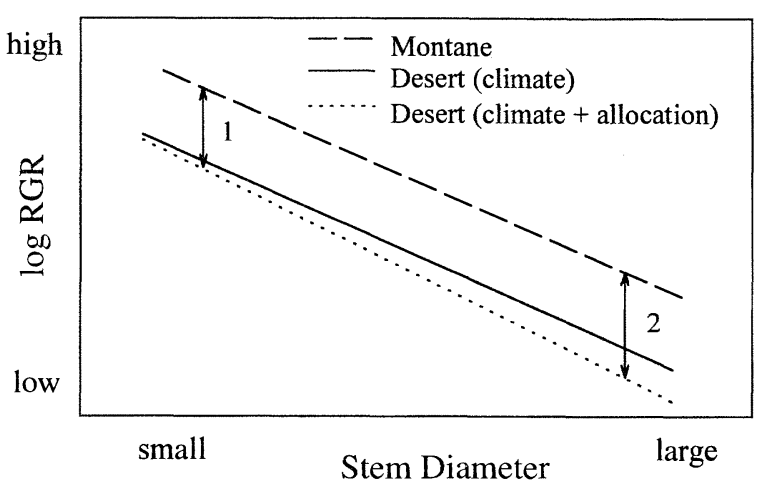

FIG. 1. Prediction of relative growth rate as a function of stem diameter ( $\mathrm{dbh}$, bole diameter at $1.4 \mathrm{~m}$ above ground level) for ponderosa pine growing in desert and montane environments. The difference in relative growth rate (RGR) between environments attributable to climatic factors (primarily water limitation) is represented by the difference between the montane and desert environments (1). An additional reduction in RGR with increasing dbh was predicted based on the proportional increase in allocation to sapwood and away from foliage for large desert trees (2).

than that for large montane trees (Callaway et al. 1994). Annual stem maintenance respiration for ponderosa pines of comparable foliage mass was greater in the desert and was attributed to higher temperatures and increased biomass allocation to bole sapwood (Carey et al. 1997). Thus, a larger proportion of fixed carbon may have been respired by stems in the desert environment. We hypothesized that greater reductions in leaf : sapwood mass ratios combined with increased allocation of carbon to stem respiration in larger desert trees should decrease growth rates in the desert compared to the montane environment, in addition to any growth reduction imposed by drought.

As part of this study, we measured relative growth rate (RGR) of desert and montane trees to assess the effects of changes in allocation and stem respiration on aboveground productivity. RGR of trees decreases logarithmically with tree age and interspecific comparisons suggest this decline is greatest in warm environments (Waring 1987). Small desert trees, with biomass allocation similar to montane trees of the same diameter, likely have low growth rates because of a direct water limitation. For larger desert trees, which allocate proportionally more biomass to sapwood and less to foliage than montane trees of the same diameter, growth rate may also be lowered by water stress and the costs of building and maintaining sapwood. Therefore, we predicted that RGR would be less in the desert environment for all tree diameters, because of environmental constraints, and that RGR would decline more with increasing stem diameter (Fig. 1).

Alternatively, desert trees may compensate for increasing allocation to sapwood (and proportionally greater stem maintenance respiration) by increased capacity for photosynthetic carbon uptake. We examined three mechanisms that could contribute to higher carbon gain in large desert trees: (1) a size-dependent increase in photosynthetic rate per unit leaf area, (2) modification of canopy architecture permitting greater light penetration and therefore increased net photosynthesis for older foliage cohorts, and (3) the maintenance of younger, more active needle cohorts through increased needle turnover. To determine if one or more of these mechanisms increase carbon gain with tree size in desert compared to montane trees, we measured photosynthetic capacity, leaf nitrogen concentration, stable-carbon isotope composition, canopy light interception, leaf area index, light extinction coefficients, and leaf demography, and examined changes in these variables as a function of stem diameter.

\section{METHODS}

\section{Study area}

Our study was conducted in the eastern Sierra $\mathrm{Ne}$ vada and adjacent Great Basin desert within $100 \mathrm{~km}$ of Reno, Nevada. In this region, ponderosa pine and other Sierran conifers can be found growing on patches of soil derived from hydrothermally altered andesite (Billings 1950, DeLucia et al. 1988, Schlesinger et al. 1989). In the warm, dry desert environment, tree islands on these altered soils are surrounded by vegetation characteristic of sagebrush steppe; in the cooler, moister montane environment they are surrounded by Sierran conifers. In both environments, trees are opengrown with nonoverlapping canopies. Soils at these sites are similar across environments with respect to nutrients, organic matter, nitrogen content, and other soil properties (e.g., C, $\mathrm{P}, \mathrm{pH}, \mathrm{Ca}^{2+}, \mathrm{HCO}_{3}^{-}$[Schlesinger et al. 1989]). Therefore, these sites provide a unique experimental system for examining the effects of climate, primarily temperature and moisture, on trees without the confounding effect of differing substrates. In addition, they provide an opportunity to test hypotheses regarding conifer growth regulation and forest productivity. Locations and climate data for sites used in the current study are given in Table 1.

\section{Relative growth rate and predicted photosynthetic rate}

Relative growth rate of bole sapwood was calculated using sections cut from trees $(n=17$ trees per environment) for a prior study (Callaway et al. 1994). Sapwood mass 5 yr previous was calculated using allometric equations relating aboveground mass to bole diameter developed from this set of trees (Callaway et al. 1994). Relative growth rate (RGR) was calculated as bole sapwood mass accumulated per unit bole sapwood mass present $5 \mathrm{yr}$ earlier, using the following equation modified from Harper (1977):

$$
\mathrm{RGR}=\left[\ln \left(\text { biomass }_{2}\right)-\ln \left(\text { biomass }_{1}\right)\right] /\left(t_{2}-t_{1}\right) .
$$

To formulate predictions of net carbon gain as a func- 
TABle 1. Topographic and climatic data for Desert and Montane sites in a study of ponderosa pines. Values given for precipitation and temperature are annual means.

\begin{tabular}{|c|c|c|c|c|}
\hline Site & Latitude/longitude & $\begin{array}{l}\text { Elevation } \\
\quad(\mathrm{m})\end{array}$ & $\begin{array}{l}\text { Precipitation } \\
\quad(\mathrm{mm} / \mathrm{yr})\end{array}$ & $\begin{array}{c}\text { Temperature } \\
\left({ }^{\circ} \mathrm{C}\right)\end{array}$ \\
\hline \multicolumn{5}{|l|}{ Desert } \\
\hline Desert Research Institute $\dagger$ & $119^{\circ} 48^{\prime} \mathrm{N}, 39^{\circ} 35^{\prime} \mathrm{W}$ & 1500 & 225 & 11.4 \\
\hline Ecology Canyon South $¥$ & $119^{\circ} 51^{\prime} \mathrm{N}, 39^{\circ} 35^{\prime} \mathrm{W}$ & 1590 & 262 & 11.0 \\
\hline Ecology Canyon North $\ddagger$ & $119^{\circ} 51^{\prime} \mathrm{N}, 39^{\circ} 35^{\prime} \mathrm{W}$ & 1610 & 218 & 11.0 \\
\hline Peavine Mountain $†$ & $119^{\circ} 53^{\prime} \mathrm{N}, 39^{\circ} 33^{\prime} \mathrm{W}$ & 1700 & 250 & 10.5 \\
\hline Ramsey Minet & $119^{\circ} 24^{\prime} \mathrm{N}, 39^{\circ} 28^{\prime} \mathrm{W}$ & 1750 & 207 & 10.5 \\
\hline \multicolumn{5}{|l|}{ Montane } \\
\hline Alpine County $1 \dagger \ddagger$ & $119^{\circ} 44^{\prime} \mathrm{N}, 38^{\circ} 41^{\prime} \mathrm{W}$ & 1830 & 550 & 7.6 \\
\hline Alpine County $2 \nmid \ddagger$ & $119^{\circ} 44^{\prime} \mathrm{N}, 38^{\circ} 41^{\prime} \mathrm{W}$ & 1890 & 565 & 7.6 \\
\hline Virginia Mountains $\nmid \ddagger$ & $119^{\circ} 41^{\prime} \mathrm{N}, 39^{\circ} 22^{\prime} \mathrm{W}$ & 1860 & 330 & 8.4 \\
\hline
\end{tabular}

$\dagger$ Locations for relative growth rate study.

$\$$ Locations for leaf and canopy study.

tion of stem diameter, we also calculated annual photosynthetic rate $\left(\mathrm{PS}_{\mathrm{a}}\right.$, in kilograms per square meter per year) for trees of different sizes from desert and montane climates by combining relative growth rate, allometry (Callaway et al. 1994), and wood respiration (Carey et al. 1997) for aboveground components in the following equation adapted from Lambers and Poorter (1992):

$$
\begin{aligned}
\mathrm{RGR}= & \left(\mathrm{PS}_{\mathrm{a}} \times \mathrm{SLA} \times \mathrm{LWR}\right)-\left(\mathrm{SR}_{\mathrm{w}} \times \mathrm{SWR}\right) \\
& -\left(\mathrm{LR}_{\mathrm{w}} \times \mathrm{LWR}\right)
\end{aligned}
$$

where RGR is relative growth rate (in kilograms of carbon per kilogram of carbon per year), SLA is specific leaf area (in square meters of leaf area per kilogram of leaf carbon), LWR is leaf mass ratio (in kilograms $C$ per kilogram $C), S_{w}$ is stem respiration rate (in kilograms $\mathrm{C}$ per kilogram sapwood $\mathrm{C}$ per year), SWR is stem mass ratio (kilograms $C$ per kilogram C), and $L_{\mathrm{w}}$ is leaf respiration rate (in kilograms $C$ per kilogram leaf $C$ ).

SLA, LWR, and SWR were calculated for trees ranging in size from 5 to $60 \mathrm{~cm}$ in diameter (dbh, bole diameter at $1.4 \mathrm{~m}$ above ground) using allometric relationships derived from harvested trees spanning this diameter range (Callaway et al. 1994). Sapwood respiration was estimated from in situ gas exchange and calorimetric estimates of construction respiration (Carey et al. 1997). $\mathrm{LR}_{w}$ and $\mathrm{PS}_{\mathrm{a}}$ were solved for simultaneously, assuming $\mathrm{LR}_{\mathrm{w}}$ was $10 \%$ of $\mathrm{PS}_{\mathrm{a}}$ (estimated as a percentage of photosynthetic capacity from values in Larcher 1995) multiplied by SLA (to convert to mass-based units).

\section{Leaf nitrogen, carbon isotope composition, and photosynthetic capacity}

To examine potential size-dependent differences in canopy gas exchange, we measured leaf nitrogen concentration, stable-carbon isotope composition, light interception, and leaf demography. We sampled 120 trees from three desert and three montane sites (Table 1). Twenty to twenty-five trees per site were divided into diameter classes (three to four trees per diameter class per site) with dbh class midpoints of: $5,15,25,35,45$, and $55 \mathrm{~cm}$.

Canopies of large trees were inaccessible for instantaneous measurements of photosynthesis. Therefore we measured leaf nitrogen concentration as a proxy for photosynthetic capacity and stable-carbon isotope composition $\left(\delta^{13} \mathrm{C}\right)$ as an indicator of internal $\mathrm{CO}_{2}$ concentration and water-use efficiency to determine if timeintegrated photosynthetic carbon gain may increase with tree diameter. Needle samples were collected by age class from each tree from the tips of sun-exposed branches at each of the four cardinal points. Samples were taken from the lower third of the canopy for all size classes at heights ranging from $0.5-8 \mathrm{~m}$ from the ground and grouped by age class and tree $(n \approx 580$ needle samples). Samples were dried and ground to pass a $600-\mu \mathrm{m}$ mesh screen size in a Wiley mill. Total Kjeldahl nitrogen was determined colorimetrically (Traacs 800, Bran + Luebbe, Elmsford, New York). Stable-carbon isotope composition was determined for 1 -yr-old foliage ground to pass a $425-\mu \mathrm{m}$ mesh $(n=$ 116 needle samples). Isotope analyses were performed by Larry Giles at the Duke University Phytotron. Samples were combusted in an elemental analyzer (NA1500, Carlo Erba, Milan, Italy) and the carbon isotope composition of $\mathrm{CO}_{2}$ derived from combustion of samples was measured with a SIRA Series II isotope mass spectrometer (VG Isotech, Middlewich, UK). The reference $\mathrm{CO}_{2}$ was calibrated against standard Pee Dee Belemnite; the accuracy was $\pm 0.1 \%$.

We measured photosynthetic capacity and leaf nitrogen concentration on a subsample of foliage to verify that leaf nitrogen was correlated with photosynthetic capacity for ponderosa pines growing at these sites. During a 10-d period in August, needles from various age classes were collected from each of the six sites. Samples were collected early in the morning and kept cool and moist $\leq 6 \mathrm{~h}$ until measurements were made in the laboratory. Photosynthetic capacity was measured as $\mathrm{O}_{2}$ evolution by needles under saturating $\mathrm{CO}_{2}(12 \%$ 
[Day et al. 1991]), irradiance $\left(2600 \mu \mathrm{mol} \cdot \mathrm{m}^{-2} \cdot \mathrm{s}^{-1}\right)$ and humidity in a gas-phase oxygen electrode (Hansatech Instruments, Norfolk, UK). The midsections of four to five fascicles were fastened together edge-to-edge forming a rectangle with adaxial side toward the light source ( $n=32$ rectangles from montane trees, $n=25$ rectangles from desert trees). Temperature inside of the chamber was maintained at $25^{\circ} \mathrm{C}$ with a chilled water bath. Total Kjeldahl nitrogen content was determined colorimetrically on dried needles (Traacs 800, Bran + Luebbe, Elmsford, New York).

\section{Light interception and leaf demography}

Light penetration into crowns of individual trees was measured using diazo paper sensors (Friend 1961), that were calibrated with a quantum sensor (LI-COR, Lincoln, Nebraska, USA) under both sun and shade conditions. Each sensor was composed of 15 layers of diazo paper (Azon \#4516 nonerasable diazo sepia paper, Azon, Johnson City, New York, USA) sandwiched between two layers of opaque cardboard. A 5-mm aperture was cut into the top layer to allow sunlight to enter; sensors were protected from the elements by sealing them inside of plastic petri dishes. The amount of photosynthetically active radiation (PPFD, in moles per square meter per second) incident on a sensor was related to the number of diazo paper layers exposed by the relationship: $\log (\mathrm{PPFD})=0.358$ (number of layers exposed) $-1.922, R^{2}=0.99$. One sensor was placed on each of five branches per tree at the base of live crown at the point where the innermost foliage was located; positioning within a tree encompassed all aspects. Sensors were collected after $24 \mathrm{~h}$. Percentage full sunlight reaching the innermost foliage was determined from the ratio of PPFD incident on canopy sensors to reference sensors placed in full sunlight. Parallel measurements of diffuse nonintercepted radiation, a measure of the gap fraction of the crown, were taken for individual trees with a plant canopy analyzer (LAI2000, LI-COR, Lincoln, Nebraska). A $45^{\circ}$ view cap was used to prevent the sensor from seeing the trunk. Measurements were made within a half-hour of sunrise ( $n=80$ trees), and 8-10 readings were taken below the canopy for each reading outside of the canopy. In addition, leaf area index (LAI) of individual trees was estimated as single-sided leaf area (from allometric relationships [Callaway et al. 1994]) per unit projected ground area. The light extinction coefficient $(k)$ was calculated using the Beer-Lambert law $\left(I=I_{0} e^{-k \mathrm{LAI}}\right)$ from LAI and the ratio of light incident at base of live crown to total incident irradiance $\left(I / I_{0}\right)$ obtained from diazo paper sensors. Light interception was measured at all montane sites and two of the three desert sites.

To compare leaf demography among diameter classes and between environments, we calculated the percentage contribution by mass of each age class to the total mass of foliage on a sample branch. Current year foliage was excluded to remove any effects related to differences in needle phenology between sites. In addition, we measured total foliated length on south-facing branches to examine size-dependent differences in foliage display.

\section{Statistical analysis}

We tested for a size-dependent relationship for all of the variables using analysis of covariance with diameter class as a covariate. Sites were nested within environments and all components of the model were random effects except for stem diameter class. The diameter class $\times$ site interaction term was not significant in any analysis and was therefore dropped from the model. Values of LAI and $k$ were $\log$ transformed to meet assumptions of normality and equal variance. No significant differences between sites, within environments were found for $\delta^{13} \mathrm{C}, \log$ LAI, $\log k$, or diffuse nonintercept radiation, therefore sites were pooled and results are presented for between-environment comparisons only. One montane site (Virginia Mountains) had lower leaf nitrogen concentrations on average than the other two montane sites. Removing this site did not effect the overall analysis, except that site (within environment) differences were no longer significant. Therefore all six sites were included in the analysis and results are presented for environments. The percentage of foliage within a cohort did not vary with size and between environment differences were tested after eliminating diameter class terms from the model. All data fit assumptions for models used. Analyses were performed using the General Linear Models procedure, Statistical Analysis Software, Version 6.11 (SAS Institute 1996).

\section{RESULTS}

\section{Relative growth rate and predicted photosynthetic rate}

Trees growing in the desert had significantly lower relative growth rates (RGRs) than montane trees (Fig. $2 \mathrm{~A}, P<0.05)$. RGRs of small trees $(6-8 \mathrm{~cm} \mathrm{dbh})$ were $\sim 0.1 \mathrm{~kg} \cdot \mathrm{kg}^{-1} \cdot \mathrm{yr}^{-1}$ in the desert and $\sim 0.3 \mathrm{~kg} \cdot \mathrm{kg}^{-1} \cdot \mathrm{yr}^{-1}$ in the montane environment. RGR decreased to 0.006 and $0.009 \mathrm{~kg} \cdot \mathrm{kg}^{-1} \cdot \mathrm{yr}^{-1}$ for large desert and montane trees, respectively. Contrary to our prediction, there was no difference in the slope of the relationship between RGR and stem diameter between environments $(P=0.25)$.

Estimated annual photosynthetic rate per unit leaf area decreased with diameter more in montane trees than in desert trees. Our calculations of $\mathrm{PS}_{\mathrm{a}}$ (in kilograms per square meter per year) suggest there are differences between environments in the relationship of photosynthetic rate as a function of stem diameter (Fig. 2B). If we assume photosynthetic activity averaging $5 \mathrm{~h} / \mathrm{d}$ for $150-200 \mathrm{~d} / \mathrm{yr}$, these annual rates yield estimates of instantaneous PS (in micromoles per square meter per second) ranging between 0.14 and $3.48 \mu \mathrm{mol} \cdot \mathrm{m}^{-2} \cdot \mathrm{s}^{-1}$. These rates are low as com- 

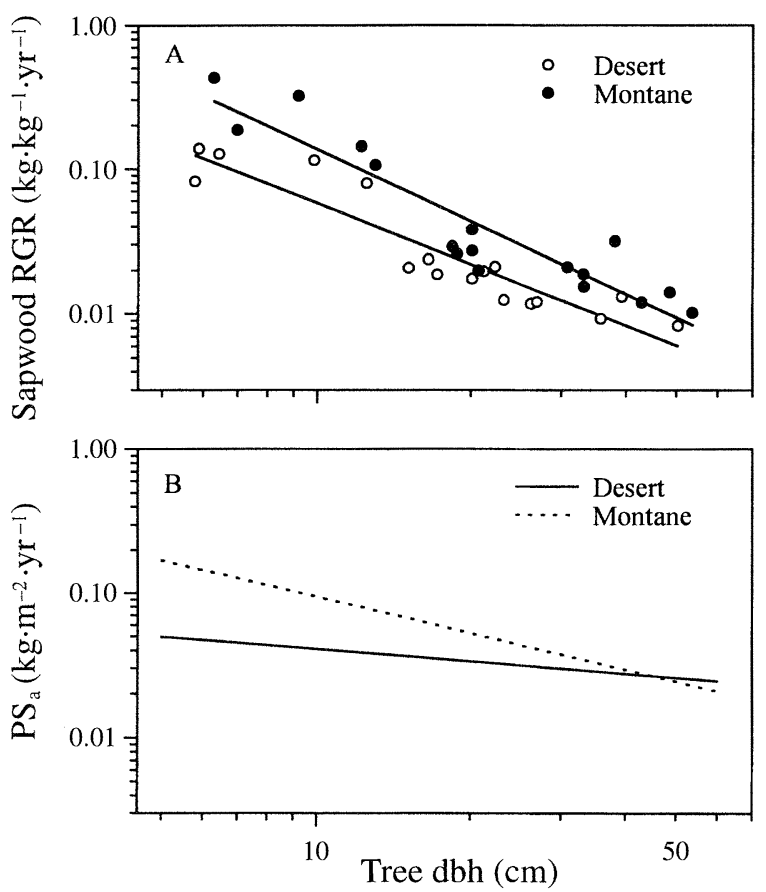

FIG. 2. Two measures of biomass acquisition and allocation for ponderosa pines growing in montane and desert environments. (A) Relative growth rates (RGR) for the $5 \mathrm{yr}$ prior to cutting of bole sapwood, regressed against stem diameter at $1.4 \mathrm{~m}$ above ground level (dbh). For montane trees, $\log \mathrm{RGR}=0.779-1.659(\log \mathrm{dbh}), R^{2}=0.90$. For desert trees, $\log \mathrm{RGR}=0.159-1.398(\log \mathrm{dbh}), R^{2}=0.93$. Environments (intercepts) were significantly different $(P<$ 0.05 ), but slopes did not differ. (B) Calculated annual net photosynthesis per unit leaf area (PS ${ }_{a}$, expressed as carbon uptake) as a function of stem diameter (dbh). Values were predicted by growth analysis from measured rates of respiration and growth (see Methods).

pared to average maximum values for net photosynthesis in conifers (3-6 $\mu \mathrm{mol} \cdot \mathrm{m}^{-2} \cdot \mathrm{s}^{-1}$ [Larcher 1995: Table 2.4]) and would be lower if belowground allocation was included in our calculations. However, our calculated rates are based on whole canopy leaf area and photosynthesis under less than optimal conditions.

\section{Leaf nitrogen, carbon isotope discrimination, and photosynthetic capacity}

Nitrogen content per unit leaf mass increased with increasing tree diameter in the desert environments for all but 6-yr-old needles, which were very few in number (Fig. 3, Table 2). In contrast, nitrogen concentration decreased with tree size or remained constant in montane needles (Fig. 3, Table 2). The intercepts (environment terms) were similar, however the slopes (diameter class $\times$ environment) differed for all but 6 -yr-old foliage, indicating that the relationship of foliar nitrogen with diameter class was different in desert vs. montane environments.

The stable-carbon isotope composition $\left(\delta^{13} \mathrm{C}\right)$ of 1-yrold needles increased with increasing stem diameter in desert trees $\left(P<0.01, R^{2}=0.21\right)$ and was constant with increasing diameter in montane trees (Fig. 4). Environments (intercepts) were significantly different and slopes differed slightly (Table 3 ). The $\delta^{13} \mathrm{C}$ values for desert and montane trees were $-22.96 \pm 0.07$ and $-24.20 \pm 0.07 \%$, respectively (mean $\pm 1 \mathrm{SE}$ ).

Photosynthetic capacity per unit leaf area (in micromoles per square meter per second), measured as $\mathrm{O}_{2}$ evolution, was positively related to leaf nitrogen concentration $(P<0.001$, Fig. 5). The slopes and intercepts were not different between environments (slope: $P>0.40$, intercept: $P>0.40$ ). Highest concentrations of leaf nitrogen and values of photosynthetic capacity were found in the desert environment (Fig. 5). Photosynthetic capacity per unit leaf mass (in nanomoles per gram per second) was also related to leaf nitrogen concentration as percentage of dry mass $\left(A_{\max }=0.671+75.64[\mathrm{~N}], R^{2}=\right.$ $0.45, P<0.001$, data not shown).

\section{Light interception and leaf demography}

The percentage of full sunlight reaching the innermost needles in the canopy decreased linearly with increasing stem diameter (Fig. 6A, Table 4). Significant differences between sites in the montane environment resulted in greater variability among sites than between environments in the overall model. However, data are presented by environment for simplicity. The range in amount of full sunlight reaching the innermost foliage was greater in the montane $(30-86 \%)$ than in the desert $(45-77 \%)$ environment. Diffuse nonintercept radiation did not vary with size or between environments $(P>0.30$, data not shown).

The relationship of log LAI of individual trees as a function of stem diameter was best described by a thirdorder polynomial regression for each environment (Fig. 6B, Table 4). Log LAI increased as a function of size before reaching a plateau and then declining, and it was greater for montane trees. Least-squares mean LAI (adjusted for diameter class) was $2.84 \pm 0.88 \mathrm{~cm}^{2}$ leaf $/ \mathrm{cm}^{2}$ ground area (mean $\pm 1 \mathrm{SE}$ ) for desert trees and $6.25 \pm$ $0.66 \mathrm{~cm}^{2} / \mathrm{cm}^{2}$ for montane trees. The relationship between $\log k$ and stem diameter was best fit by a second-order polynomial (Fig. 6C, Table 4). Log $k$ of single trees decreased with size in both environments, leveled at larger stem diameters, and was greater for desert trees compared to montane trees. The least-squares mean light extinction coefficient was greater for desert trees $(k=0.23 \pm 0.03$ vs. $0.11 \pm 0.02)$. Slope coefficients for linear, quadratic, and cubic (log LAI only) terms were the same in both environments for $\log$ LAI and $\log k(P>0.20)$, and therefore, the diameter $\times$ environment terms were dropped from the model.

The contribution of a single needle cohort to total foliage mass was independent of stem diameter for all age classes, but the percentage of total foliage in each age class differed between environments. Desert trees retained fewer age cohorts of needles than montane trees and the majority of foliage in desert trees was in younger needles 


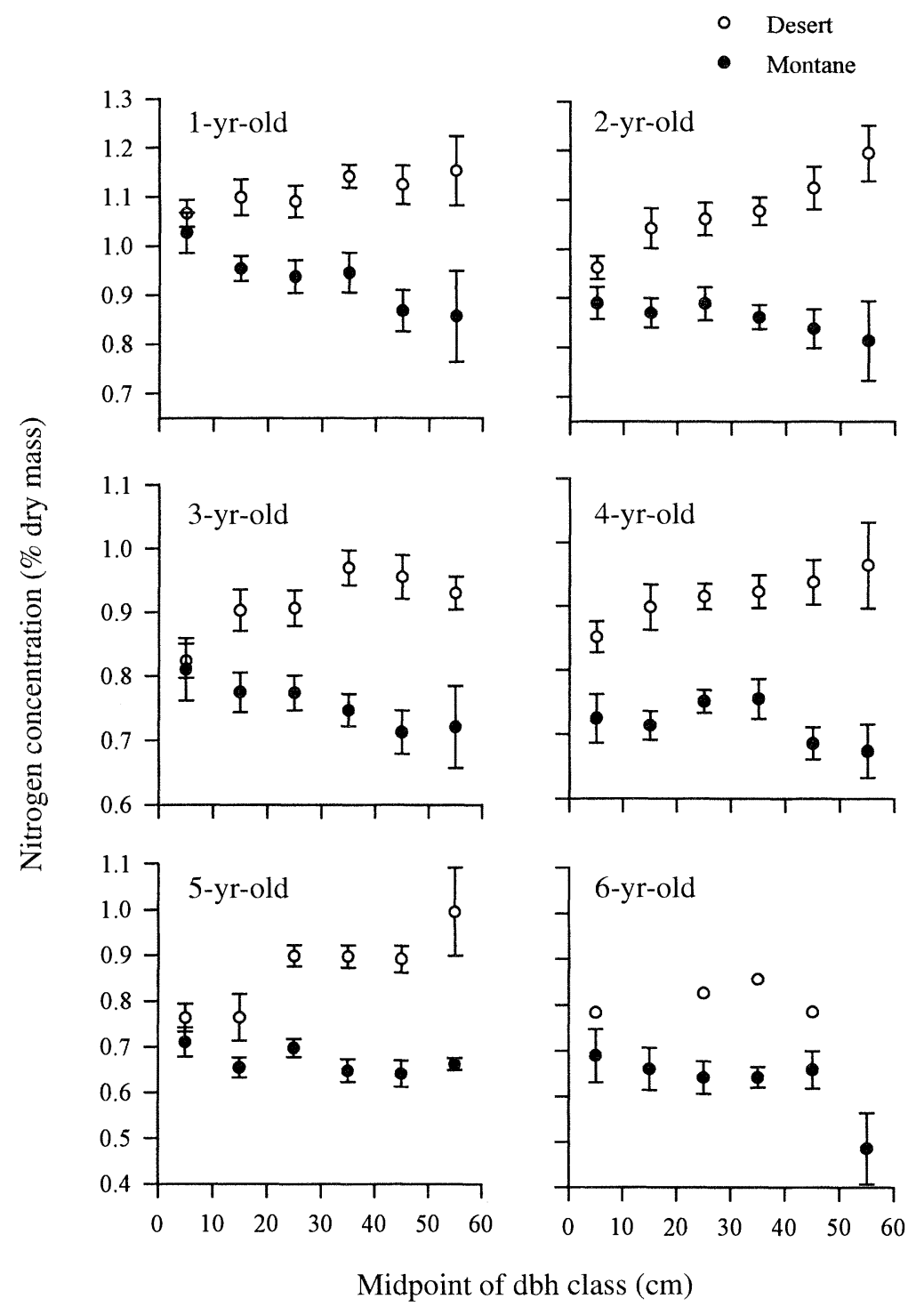

FIG. 3. Leaf nitrogen concentration as a function of stem diameter (dbh) class for 1-yr-old through 6-yr-old ponderosa pines growing in montane and desert environments. ( $\mathrm{N}$ concentration was used as a surrogate for photosynthetic rate because some needles were physically inaccessible for continuous rate measurement.) Each symbol represents the mean ( $\pm 1 \mathrm{SE}$ ) of 3-15 trees per diameter class, per environment, with the exception of 6-yr-old desert foliage. Analysis of covariance was performed on raw data rather than means. Leaf nitrogen concentration increased with tree size in all but 6-yr-old desert needles and declined or remained constant with size in montane needles. (Results of covariance analysis are presented in Table 2.)

(Fig. 7). Total foliated length on south-facing branches was the same in both environments (desert, $7.28 \pm 0.39$ $\mathrm{cm}[$ mean $\pm 1 \mathrm{SE}]$; montane, $7.39 \pm 0.40 \mathrm{~cm}, P=0.53)$ and did not vary as a function of tree size $(P=0.37$, data not shown).

\section{DisCUSSION}

The primary factor limiting plant growth in desert environments is water, and the consistently lower relative growth rates (RGRs) in desert compared to montane trees reflect this limitation. We hypothesized that allocation may impose an additional constraint on relative growth rate of desert trees. In contrast to montane trees, desert trees allocate proportionally more biomass to sapwood and less to leaves as they increase in size (Callaway et al. 1994). In addition, the respiratory cost of maintaining high sapwood mass is greater in the desert environment (Carey et al. 1997). Therefore, we predicted that RGR of desert trees would decrease more with increasing stem diameter (dbh) than RGR of montane trees. However, despite leaf : sapwood mass ratios 30-50\% lower for desert trees, RGRs decreased equally with dbh in both environments. Thus, we did not find a growth reduction 
TABLE 2. Covariance analysis for leaf nitrogen concentration as a function of stem diameter class (dbh) for 1-yr-old through 6-yr-old ponderosa pine foliage.

\begin{tabular}{cclcccc}
\hline \hline Needle & & & & \multicolumn{3}{c}{ dbh $\times$} \\
age $(\mathrm{yr})$ & $n$ & Environment & Slope & $P$ & Envt & $R^{2}$ \\
\hline 1 & 55 & desert & + & $\dagger$ & $* *$ & 0.54 \\
& 65 & montane & - & $* *$ & & \\
2 & 56 & desert & + & $* *$ & $* *$ & 0.63 \\
& 63 & montane & & N.S. & & \\
3 & 56 & desert & + & $* *$ & $* *$ & 0.57 \\
& 62 & montane & - & $\dagger$ & & \\
4 & 50 & desert & + & $*$ & $*$ & 0.68 \\
& 57 & montane & & N.s. & & \\
5 & 25 & desert & + & $* *$ & $* *$ & 0.75 \\
& 54 & montane & & N.s. & & \\
6 & 4 & desert & & N.s. & N.S. & 0.61 \\
& 32 & montane & & N.s. & & \\
\hline
\end{tabular}

Notes: Slope sign indicates the direction of slope (positive or negative) of foliar nitrogen concentration (percentage of dry mass) as a linear function of diameter class. Asterisks indicate significance ( $P$ values) of linear slope and differences between environments (dbh $\times$ Envt interaction) in the relationship of foliar nitrogen with diameter class. Environments (intercepts) were not different $(P>0.2$ for all needle ages). The $R^{2}$ values are for the covariance model.

$\dagger P<0.1, * P<0.05$, ** $P<0.01$, N.s. not significant.

associated with increased allocation to sapwood as predicted by current models of forest productivity.

Our analysis of relative growth rates reflects aboveground growth only. Differences in root growth could potentially explain the absence of diverging growth rates of desert and montane trees with increasing size (Fig. 1). If root growth was more rapid in the montane environment, then whole-tree RGRs of montane trees may have actually decreased less with dbh than we report (Fig. 2A).

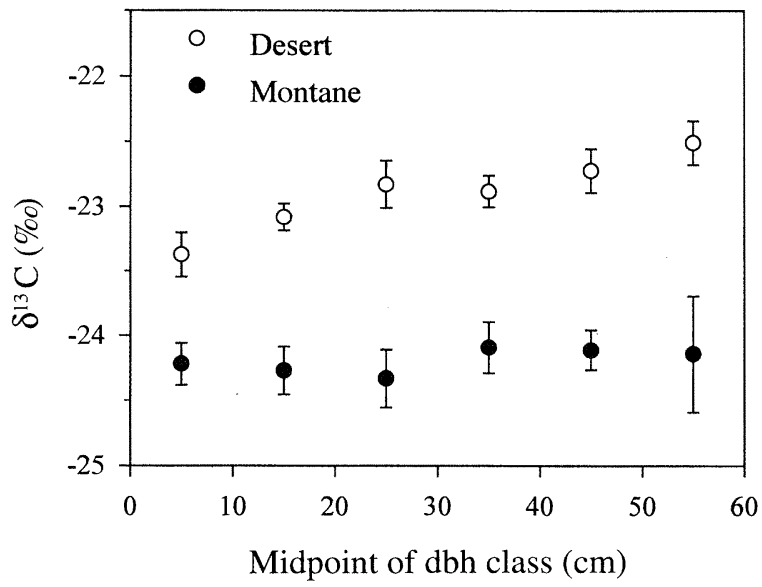

FIG. 4. Stable-carbon isotope composition $\left(\delta^{13} \mathrm{C}\right)$ as a function of stem diameter ( $\mathrm{dbh}$ ) class for needles of 1-yr-old ponderosa pine growing in montane and desert environments. Each symbol represents the mean $( \pm 1 \mathrm{SE})$ of 4-14 trees per diameter class in each environment. Analysis of covariance was performed on raw data rather than means; results are presented in Table 3. In desert trees, $\delta^{13} \mathrm{C}$ content increased with increasing dbh $(P<0.001)$.
TABLE 3. Analysis of covariance comparing carbon isotope composition of 1 -yr-old foliage from ponderosa pines grown in desert and montane environments.

\begin{tabular}{lrccc}
\hline \hline \multicolumn{1}{c}{ Source of variation } & df & MS & $P$ & $\begin{array}{c}\text { Model } \\
R^{2}\end{array}$ \\
\hline Environment (Envt) & 1 & 7.0109 & 0.0001 & 0.61 \\
Site within Environment & 4 & 0.4215 & 0.2313 & \\
Diameter class $($ dbh) & 1 & 2.2106 & 0.0074 & \\
Interaction (dbh $\times$ Envt) & 1 & 0.8031 & 0.1026 & \\
Error & 108 & 0.2962 & & \\
\hline
\end{tabular}

However, biomass allocated to roots generally increases when plants are subjected to water stress (Waring and Schlesinger 1985, Waring 1987, Wilson 1988). Thus, we expect that proportional root productivity would be even higher for desert trees than for montane trees, and it is possible that we have overestimated the difference in RGRs between these two environments (Fig. 2A).

Calculations of photosynthetic rates suggested that size-dependent differences existed between environments and rates declined with tree size (Fig. 2A). However, the decline in photosynthetic rate per unit leaf area estimated in part from observed RGRs was much less in the desert. Based on these calculations, we hypothesized that large desert trees may compensate for increased allocation to sapwood by increasing canopy carbon gain through a sizedependent increase in photosynthetic rate per unit leaf area, modification of canopy architecture, or retention of younger, more active needle cohorts. All of these variables differed between desert and montane trees, but only leaf nitrogen concentration and stable-carbon isotope composition $\left(\delta^{13} \mathrm{C}\right)$, indicators of photosynthetic capacity (Field and Mooney 1986) and time-integrated $\mathrm{CO}_{2}$ concentration within the leaf mesophyll (Farquhar et al. 1982), differed as a function of stem diameter between environments.

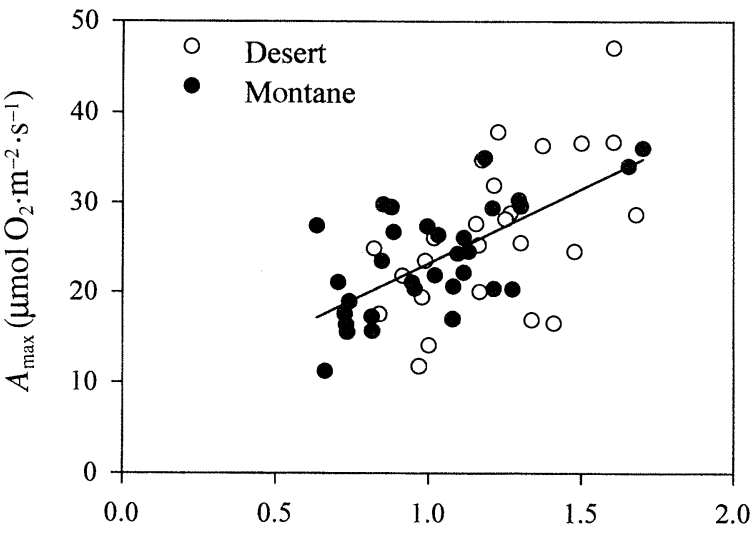

Nitrogen concentration (\% dry mass)

FIG. 5. Photosynthetic capacity $\left(A_{\max }\right)$, measured as $\mathrm{O}_{2}$ evolution, as a function of leaf nitrogen concentration in montane $(n=32$ needle samples $)$ and desert $(n=27$ needle samples) ponderosa pine populations. For environments combined, $A_{\max }=2.16+19.98(\% \mathrm{~N}), R^{2}=0.47, P<0.001$. 


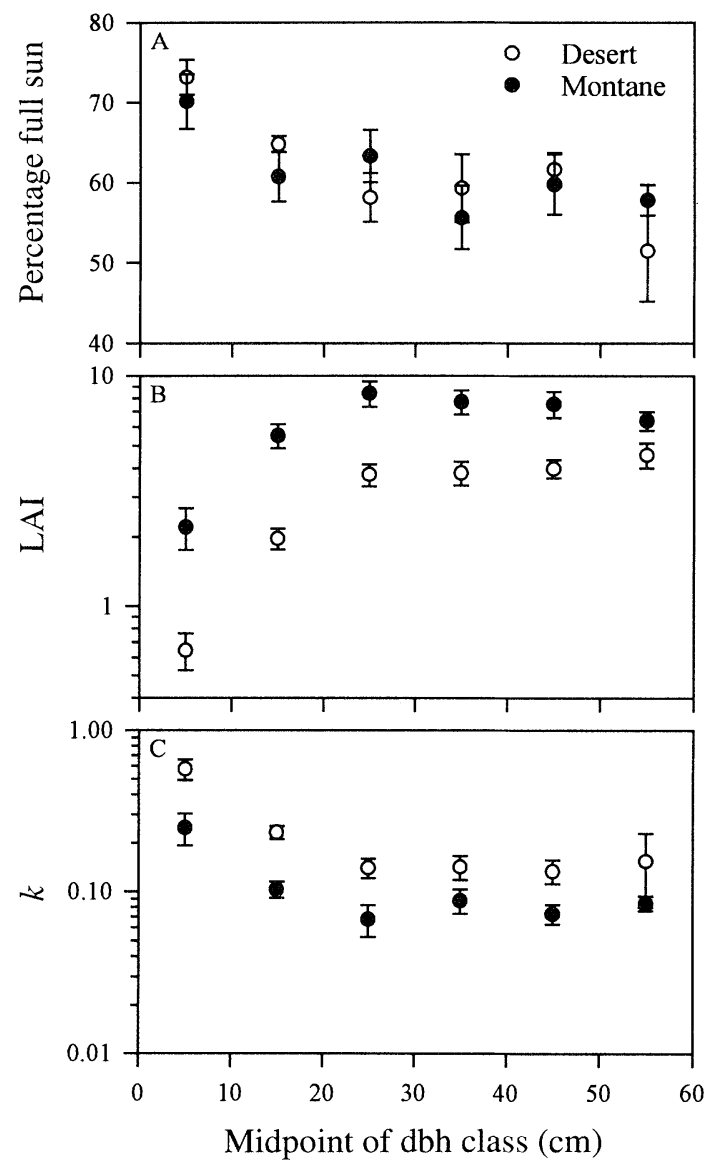

FIG. 6. Three energy-acquisition features as a function of stem diameter ( $\mathrm{dbh}$ ) class, for individual montane and desert ponderosa pines. Data show (A) light penetration into the base of the live crown, (B) leaf area index (LAI), and (C) light extinction coefficient $(k)$ for individual trees. Note $\log$ scale on the ordinate. Each symbol represents the mean $( \pm 1$ $\mathrm{SE}$ ) of 3-14 trees per stem diameter ( $\mathrm{dbh}$ ) class, per environment. Analysis of covariance was performed on raw data rather than means; results are presented in Table 4.

Leaf nitrogen concentration and carbon isotope composition were examined to assess differences in seasonally integrated photosynthetic capacity. The slopes of leaf nitrogen concentration as a function of stem diameter were different for desert vs. montane trees (Fig. 3); nitrogen concentration of needles increased with tree size in the desert environment. Trees growing in dry environments may allocate more carbon to root growth (Waring and Schlesinger 1985, Waring 1987, Santantonio 1989), and consequently nitrogen and other minerals taken up by the plant may concentrate in the foliage (Waring and Schlesinger 1985). Large desert trees with proportionally more conducting tissue and less leaf area are more likely to accumulate nutrients in this fashion than small desert trees. The relationship between measured photosynthetic capacity and leaf nitrogen concentration (Fig. 5) suggests that increased leaf nitrogen concentration in large desert trees results in greater photosynthetic capacity.
Needle nitrogen decreased or remained constant across size classes in montane trees, similar to results for bristlecone pine (Pinus aristata) and lodgepole pine (Pinus contorta) (Shoettle 1994). Age and presumably size-related reductions in photosynthetic capacity have been reported for Norway spruce (Picea abies) and Pinus pumila (Kull and Koppel 1987, Kajimoto 1990). In contrast to the decrease in leaf nitrogen and photosynthetic capacity in our montane population and these other studies, the increasing photosynthetic capacity in desert trees may partially offset the large investment in sapwood and maximize aboveground growth.

Leaf carbon isotope composition represents discrimination against the heavy isotope of carbon $\left({ }^{13} \mathrm{C}\right)$ during photosynthesis, and in $\mathrm{C}_{3}$ plants it is negatively correlated with time-integrated $\mathrm{CO}_{2}$ concentration within the leaf mesophyll $\left(c_{i}\right)$ and positively correlated with integrated water-use efficiency (Farquhar et al. 1982, 1989, Ehleringer 1993). Within the desert environment, $\delta^{13} \mathrm{C}$ values increased, thus $c_{i}$ decreased with increasing stem diameter (Fig. 4). Lower $c_{i}$ in needles of larger desert trees combined with higher photosynthetic capacity, inferred from higher leaf nitrogen concentrations (Fig. 3), could result from either higher photosynthetic rates or stomatal limitation to photosynthesis. If photosynthetic capacity increases with tree size, and stomatal conductance remains constant (or increases) with size, then higher $\delta^{13} \mathrm{C}$ and lower $c_{i}$ s would result from higher photosynthetic rates. Conversely, if photosynthetic capacity increases and stomatal conductance decreases with tree size, then lower $c_{i} \mathrm{~s}$ could be interpreted as greater stomatal limitation to photosynthesis in large desert trees. Both the observed relative growth rates and modeled photosynthetic rates (Fig. 2A, B) support the former interpretation.

Comparable patterns of leaf nitrogen concentration and stable isotope composition have been observed in other studies (Donovan and Ehleringer 1994, Rasmuson et al. 1994). Although greater $\delta^{13} \mathrm{C}$ values and, by association, greater water use efficiency are often associated with lower rates of photosynthesis and stomatal conductance, Rasmuson et al. (1994) reported higher nitrogen concentrations, stable isotope compositions and stomatal conductances in southern facing rosettes of Joshua trees (Yucca brevifolia) growing in the Mojave desert, indicative of higher rates of carbon gain in these rosettes. Similar to our results for ponderosa pine, Donovan and Ehleringer (1994) found size-dependent differences in leaf nitrogen concentration and stable-carbon isotope composition within a population of rabbitbrush (Chrysothamnus nauseosus) in the Great Basin Desert. Juvenile rabbitbrush shrubs had lower leaf nitrogen concentrations (Donovan and Ehleringer 1992) and stable-carbon isotope contents than adults, and water-use efficiency was positively correlated with plant size (Donovan and Ehleringer 1994). These results for Joshua trees, rabbitbrush, and ponderosa pine demonstrate that among individuals (or rosettes) differing in photosynthetic capacity, lower carbon isotope discrimination may be related to greater rates of photo- 
TABLE 4. Analysis of covariance comparing three energy-acquisition features of ponderosa pines growing in desert and montane environments.

\begin{tabular}{|c|c|c|c|c|}
\hline Source of variation & df & MS & $P$ & Model $R^{2}$ \\
\hline \multicolumn{5}{|l|}{ Percentage full sunlight $\dagger$} \\
\hline Environment (Envt) & 1 & 0.0016 & 0.6763 & 0.29 \\
\hline Site within Environment & 3 & 0.0162 & 0.0004 & \\
\hline Diameter class (dbh) & 1 & 0.1635 & 0.0001 & \\
\hline Interaction $(\mathrm{dbh} \times$ Envt $)$ & 1 & 0.0005 & 0.8162 & \\
\hline Error & 88 & 0.0091 & & \\
\hline \multicolumn{5}{|l|}{ Log leaf area index } \\
\hline Environment (Envt) & 1 & 2.5454 & 0.0001 & 0.74 \\
\hline Site within Environment & 3 & 0.0821 & 0.0628 & \\
\hline Diameter class $(\mathrm{dbh})$ & 1 & 1.6366 & 0.0001 & \\
\hline Interaction $(\mathrm{dbh} \times \mathrm{dbh})$ & 1 & 0.7608 & 0.0001 & \\
\hline Interaction $(\mathrm{dbh} \times \mathrm{dbh} \times \mathrm{dbh})$ & 1 & 0.4419 & 0.0004 & \\
\hline Error & 88 & 0.3254 & & \\
\hline \multicolumn{5}{|l|}{ Log light extinction coefficient } \\
\hline Environment (Envt) & 1 & 2.2141 & 0.0001 & 0.57 \\
\hline Site within Environment & 3 & 0.0647 & 0.2389 & \\
\hline Diameter class (dbh) & 1 & 1.8069 & 0.0001 & \\
\hline Interaction $(\mathrm{dbh} \times \mathrm{dbh})$ & 1 & 1.0942 & 0.0001 & \\
\hline Error & 83 & 0.0451 & & \\
\hline
\end{tabular}

$\dagger$ Percentage of full sunlight reaching the innermost foliage at base of live crown.

synthetic carbon gain. In the desert environment of our study, large trees may have more access to soil water than smaller trees. If water is available to support high rates of transpiration in the hot, high-light desert environment, large trees may maximize water-use efficiency by increasing photosynthesis rather than decreasing water loss through stomatal closure (Mooney and Gulmon 1979).

Foliage from desert trees had higher $\delta^{13} \mathrm{C}$ values and there was a slightly significant diameter class $\times$ environment interaction $(P=0.10)$, indicating a differential response of carbon isotope composition as a function of diameter between desert and montane trees. Generally, species at higher elevations have greater (less negative)

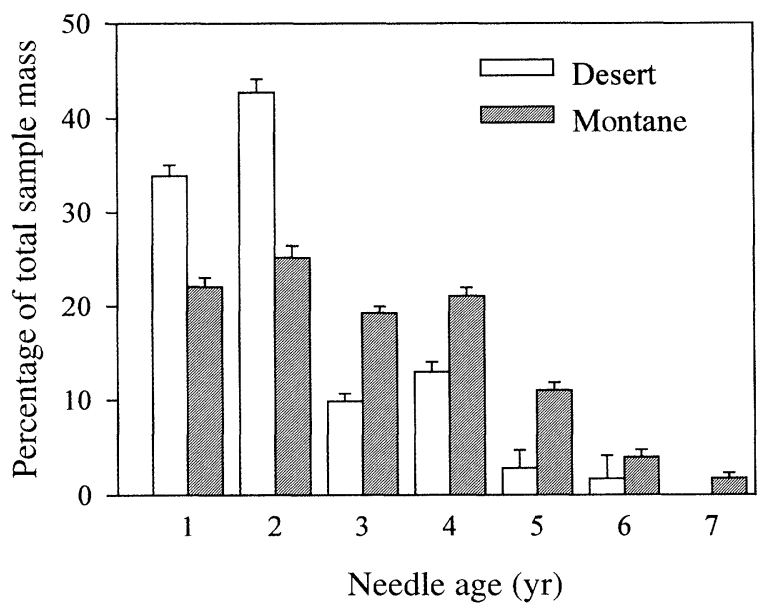

FIG. 7. Percentage of total foliage mass per sample by needle age class of desert and montane ponderosa pines. Each data bar represents the mean (and $1 \mathrm{SE}$ ) of 3-14 trees per stem diameter (dbh) class, per environment. Mean percentage foliar mass of needles of all age classes differed significantly between desert and montane environments $(P<0.05)$. carbon isotope ratios and therefore photosynthesize at lower ratios of internal to external $\mathrm{CO}_{2}$ (Körner 1989, Marshall and Zhang 1993); higher ratios may result from a steeper $\mathrm{CO}_{2}$ concentration gradient from the atmosphere to the chloroplast in thicker leaves (Marshall and Zhang 1993). In this study, we found the opposite trend. The lower ${ }^{13} \mathrm{C}$ content of montane needles is most likely caused by greater evaporative demand in the desert environment of our study.

Differences in leaf area index (LAI) and light extinction coefficient $(k)$ suggest differences in crown architecture for trees from desert and montane environments. Unlike leaf nitrogen concentration and $\delta^{13} \mathrm{C}$ values, the change in LAI and $k$ as a function of tree size was parallel in the two environments. Leaf area index increased with tree size and was greater in the montane environment. The light extinction coefficient is a measure of the fraction of light absorbed per unit leaf area as light passes through the canopy; with respect to canopy structure, $k$ is influenced by leaf orientation (horizontal to vertical), leaf arrangement (clumped vs. uniform), and leaf optical properties (Nobel et al. 1993). The light extinction coefficient decreased with tree size and leaf area as is common for stands and individual trees (Mencuccini and Grace 1996) and was greater for desert trees. Values for individual open-grown trees were lower than values for a typical canopy (LAI $=0.3-1.3[$ Nobel et al. 1993]). Greater $k$ values, in conjunction with similar percentages of full sunlight reaching the innermost foliage $\left(I / I_{0}\right)$ and smaller LAIs, suggest that desert canopies are more efficient at light absorption (more photons absorbed per unit leaf area) and that desert foliage may be less clumped (Stenberg et al. 1995) or less reflective (Waring and Schlesinger 1985). The light extinction coefficients may also reflect a difference between desert and montane trees in the amount of light absorbed by 
foliage relative to stems and branches. Greater nitrogen concentrations and thus greater chlorophyll content in desert needles (Evans 1989) may also facilitate light absorption. However, these higher nitrogen concentrations in needles also increase the construction cost of foliage (Williams et al. 1987).

Desert trees had fewer needle age classes than montane trees. Retaining young, more efficient foliage may result in maximum stem production for desert trees. However, retention of a greater proportion of older foliage was associated with higher RGRs in montane trees and higher stem biomass production in Scots pine $(\mathrm{Ku}-$ uluvainen and Kainninen 1992). We found no relationship between needle retention and tree size. Foliated length was also the same between environments and for size classes within an environment. Fewer foliage age classes distributed along a similar length of branch may result in more efficient light use by less self-shaded needles within a branch in desert trees. Our data for leaf demography and canopy structure imply that desert canopies may be more efficient at light capture and utilization, but they do not explain size-dependent differences in canopy carbon gain.

Trees respond to growth environment through changes in biomass allocation and physiology. Within an environment, allocation and physiology can change as a function of tree size (age). As they increase in size, desert-grown ponderosa pines may compensate for the cost of building and maintaining proportionally greater sapwood volume by increasing, or at least maintaining, carbon gain per unit leaf mass. Higher leaf nitrogen concentrations in larger trees, combined with greater light extinction coefficients and less self-shading, contribute to maximum canopy efficiency in the desert environment. Increased photosynthetic capacity in large desert trees as compared to small desert trees may be possible due to the greater water conducting capacity provided by proportionally greater sapwood volumes. Overall, these data demonstrate that increased allocation to heterotrophic stem tissue at the expense of photosynthetic tissue does not always incur a reduction in tree growth as predicted by current models of forest productivity.

\section{ACKNOWLEDGMENTS}

We would like to thank Dr. Harold Klieforth of the Atmospheric Sciences Center, Desert Research Institute, Reno, Nevada for providing climate data and the Desert Research Institute for providing laboratory space and logistical support. E. V. Carey was supported by a DOE/NSF/USDA Interdisciplinary Research Training Grant for Integrative Photosynthesis Research (DOE 92ER20095). Additional support was provided by a USDA NRI grant (Ecosystems: AG94-371010562) to E. H. DeLucia.

\section{Literature CITED}

Billings, W. D. 1950. Vegetation and plant growth as affected by chemically altered rocks in the western Great Basin. Ecology 31:62-74.

Callaway, R. M., E. H. DeLucia, and W. H. Schlesinger. 1994. Biomass allocation of montane and desert ponderosa pine: an analog for response to climate change. Ecology $\mathbf{7 5}$ : $1474-1481$.

Carey, E. V., R. M. Callaway, and E. H. DeLucia. 1997. Stem respiration of ponderosa pines grown in contrasting climates: implications for global climate change. Oecologia (Berlin) 111:19-25.

Day, T. A., S. A. Heckathorn, and E. H. DeLucia. 1991. Limitations of photosynthesis in Pinus taeda L. (loblolly pine) at low soil temperatures. Plant Physiology 96:12461254.

DeLucia, E. H., W. H. Schlesinger, and W. D. Billings. 1988. Water relations and the maintenance of Sierran conifers on hydrothermally altered rock. Ecology 69:303-311.

Donovan, L. A., and J. R. Ehleringer. 1992. Contrasting water-use patterns among size and life-history classes of a semi-arid shrub. Functional Ecology 6:482-488.

Donovan, L. A., and J. R. Ehleringer. 1994. Carbon isotope discrimination, water-use efficiency, growth and mortality in a natural shrub population. Oecologia (Berlin) 100:347354.

Ehleringer, J. R. 1993. Carbon and water relations in desert plants: an isotopic perspective. Pages $152-172$ in J. R. Ehleringer, A. H. Hall, and G. D. Farquhar, editors. Stable isotopes and plant carbon-water relations. Academic Press, Pleasant Hill, California, USA.

Evans, J. R. 1989. Photosynthesis and nitrogen relationships in leaves of $\mathrm{C}_{3}$ plants. Oecologia (Berlin) 78:9-19.

Farquhar, G. D., M. H. O'Leary, and J. A. Berry. 1982. On the relationship between carbon isotope discrimination and intercellular carbon dioxide concentration in leaves. Australian Journal of Plant Physiology 9:121-137.

Farquhar, G. D., J. R. Ehleringer, and K. T. Hubick. 1989. Carbon isotope discrimination and photosynthesis. Annual Review of Plant Physiology and Plant Molecular Biology 40:503-537.

Field, C., and H. A. Mooney. 1986. The photosynthesisnitrogen relationship in wild plants. Pages $25-55$ in T. J. Givnish, editor. On the economy of plant form and function. Cambridge University Press, New York, New York, USA.

Friend, D. T. C. 1961. A simple method of measuring integrated light values in the field. Ecology 42:577-580.

Gower, S. T., J. G. Isebrands, and D. W. Sheriff. 1995. Carbon allocation and accumulation in conifers. Pages $217-254$ in W. K. Smith and T. M. Hinckley, editors. Resource physiology of conifers: acquisition, allocation, and utilization. Academic Press, New York, New York, USA.

Harper, J. L. 1977. Population biology of plants. John Wiley and Sons, New York, New York, USA.

Kajimoto, T. 1990. Photosynthesis and respiration of Pinus pumila needles in relation to needle age and season. Ecological Research 5:333-340.

Körner, C. 1989. The nutritional status of plants from high altitudes. Oecologia (Berlin) 81:379-391.

Kull, O., and A. Koppel. 1987. Net photosynthetic response to light intensity of shoots from different crown positions and age in Picea abies (L.) Karst. Scandinavian Journal of Forest Research 2:157-166.

Kuuluvainen, T., and M. Kanninen. 1992. Patterns in aboveground carbon allocation and tree architecture that favor stem growth in young Scots pine from high latitudes. Tree Physiology 10:69-80.

Lambers, H., and H. Poorter. 1992. Inherent variation in growth rate between higher plants: a search for physiological causes and ecological consequences. Advances in Ecological Research 23:187-261.

Larcher, W. 1995. Physiological plant ecology. Springer-Verlag, New York, New York, USA.

Marshall, J. D., and J. Zhang. 1993. Altitudinal variation in carbon isotope discrimination by conifers. Pages 187-199 in J. R. Ehleringer, A. H. Hall, and G. D. Farquhar, editors. 
Stable isotopes and plant carbon-water relations. Academic Press, Pleasant Hill, California, USA.

Mencuccini, M., and J. Grace. 1995. Climate influences the leaf area/sapwood area ratio in Scots pine. Tree Physiology 15: $1-10$.

Mencuccini, M., and J. Grace. 1996. Hydraulic conductance, light interception and needle nutrient concentration in Scots pine stands and their relations with net primary productivity. Tree Physiology 16:459-468.

Mooney, H. A. and S. L. Gulmon. 1979. Environmental and evolutionary constraints on the photosynthetic characteristics of higher plants. Pages 316-337 in O. T. Solbrig, S. Jain, G. B. Johnson, and P. H. Raven, editors. Topics in plant population biology. Columbia University Press, New York, New York, USA.

Nobel, P. S., I. N. Forseth, and S. P. Long. 1993. Canopy structure and light interception. Pages 79-90 in D. O. Hall, J. M. O. Scurlock, H. R. Bolhàr-Nordenkampf, R. C. Leegood, and S. P. Long, editors. Photosynthesis and production in a changing environment: a field and laboratory manual. Chapman and Hall, New York, New York, USA.

Poorter, H., C. Remkes, and H. Lambers. 1990. Carbon and nitrogen economy of 24 wild species differing in relative growth rate. Plant Physiology 94:621-627.

Rasmuson, K. E., J. E. Anderson, and N. Huntly. 1994. Coordination of branch orientation and photosynthetic physiology in the Joshua tree (Yucca brevifolia). Great Basin Naturalist 54:204-211.
Santantonio, D. 1989. Dry-matter partitioning and fine-root production in forests - new approaches to a difficult problem. Pages 57-72 in J. S. Pereira and J. J. Landsberg, editors. Biomass production by fast-growing trees. Kluwer Academic, Dordrecht, The Netherlands.

Schlesinger, W. H., E. H. DeLucia, and W. D. Billings. 1989 Nutrient-use efficiency of woody plants on contrasting soils in the western Great Basin, Nevada. Ecology 70:105-113.

Shoettle, A. W. 1994. Influence of tree size on shoot structure and physiology of Pinus contorta and Pinus aristata. Tree Physiology 14:1055-1068.

Stenberg, P., E. H. DeLucia, A. W. Shoettle, and H. Smolander. 1995. Photosynthetic light capture and processing from cell to canopy. Pages 3-38 in W. K. Smith and T. M. Hinckley, editors. Resource physiology of conifers: acquisition, allocation, and utilization. Academic Press, New York, New York, USA.

Waring, R. H. 1987. Characteristics of trees predisposed to die. BioScience 37:569-574.

Waring, R. H., and W. H. Schlesinger. 1985. Forest ecosystems concepts and management. Academic Press, New York, New York, USA.

Williams, K., F. Percival, J. Merino, and H. A. Mooney. 1987. Estimation of tissue construction cost from heat of combustion and organic nitrogen content. Plant, Cell and Environment 10:725-734.

Wilson, J. B. 1988. A review of evidence on the control of shoot : root ratio in relation to models. Annals of Botany 61:433-449. 